\title{
Wall rock alteration in part of the Sarnak gold deposit, SE Bulgaria. Preliminary data
}

\section{Околорудни изменения в част от златно находище Сърнак, ЮИ България. Предварителни данни}

\author{
Aleksandar Gadzhalov, Irina Marinova \\ Александър Гаджалов, Ирина Маринова
}

Institute of Mineralogy and Crystallography, Bulgarian Academy of Sciences, Acad. G. Bonchev Str., Bl. 107, 1113 Sofia;

E-mail: aleksandar.gadzhalov@yahoo.es

\begin{abstract}
This short communication presents preliminary data on a wall rock alteration in part of the Sarnak epithermal gold deposit based on host rock samples from drill hole cores. Methods used are powder X-ray diffraction as well as optical and scanning electron microscopy. The most pronounced alterations related to the epithermal mineralization are vein silicification, adularization and pyritization.
\end{abstract}

Keywords: wall rock alteration, metamorphic basement, sedimentary cover, pyritization, Sarnak gold deposit.

\section{Introduction}

The Sarnak deposit is of epithermal type with propylitic, adularia-sericite (fault-related) and argillic wall rock alterations (Kunov et al., 1999). Pyrite is the main ore mineral as it is arsenian in composition with an alternation of As-rich and As-poor microbands (Marton, 2009; unpubl. data of the authors). We observed gold and electrum in pyrite, optically and by SEM. Marton (2009) proposed that sulphidation of the host rock Fe and change in the oxidation state had the greatest effect on Au and As solubility in deposits like Sarnak. This idea directed our research to characterize the wall rock alteration in the immediate proximity of pyrite veinlets (from a few to $\sim 10-20 \mathrm{~cm}$ away) and its relationship with the epithermal mineralization.

\section{Material and methods}

Seven host rock samples from drill hole cores (drilling of Dundee Precious Metals Kroumovgrad, DPMK, in the last 15 years) have been used. Generally, all drill holes, excepting SUDD033, intersect a N-S striking $\left(10^{\circ}\right)$ and moderately to steeply dipping $\left(60-65^{\circ}\right)$ to the east ore zone. The zone comprises few $\mathrm{cm}$ wide veins, mainly of quartz- pyrite composition. Surface location of the drill holes, their horizontal traces and location of samples are plotted on the geological map of the deposit (Fig. 1a). Some of the studied samples are marked on Fig. 1b-d with white ellipse/circle, indicating the areas of thin sections. The mineral composition was defined, using powder X-ray diffraction $\left(3-100^{\circ} 2 \theta\right.$ range, $0.13^{\circ}$ step, 70 sec time per step, $30 \mathrm{~mA}$, Cu radiation $(\lambda=1.5406 \AA)$ and PIXcel ${ }^{3 \mathrm{D}}$ detector at $40 \mathrm{kV}$, Empyrean powder X-ray diffractometer, Malvern Panalytical, Netherlands), optical microscopy and SEM (Zeiss Evo LS25 microanalyzer, Germany) equipped with analytical system EDAX TRIDENT (EDS+WDS+EBSD).

\section{Local geology}

The Sarnak deposit is a part of the Kroumovgrad goldfield, Eastern Rhodope Mts and is hosted within and next to a tectonically reworked contact of the high-grade metamorphic basement and overlying sedimentary cover (drill hole data of DPMK). The metamorphic basement is uplifted and forms the Sarnak Horst, while the sediments were deposited in the Sarnak Graben. The metamorphic basement consists of pre-Paleocene granitic pegmatites, marbles and calc-shists, amphibolites, amphibole and 

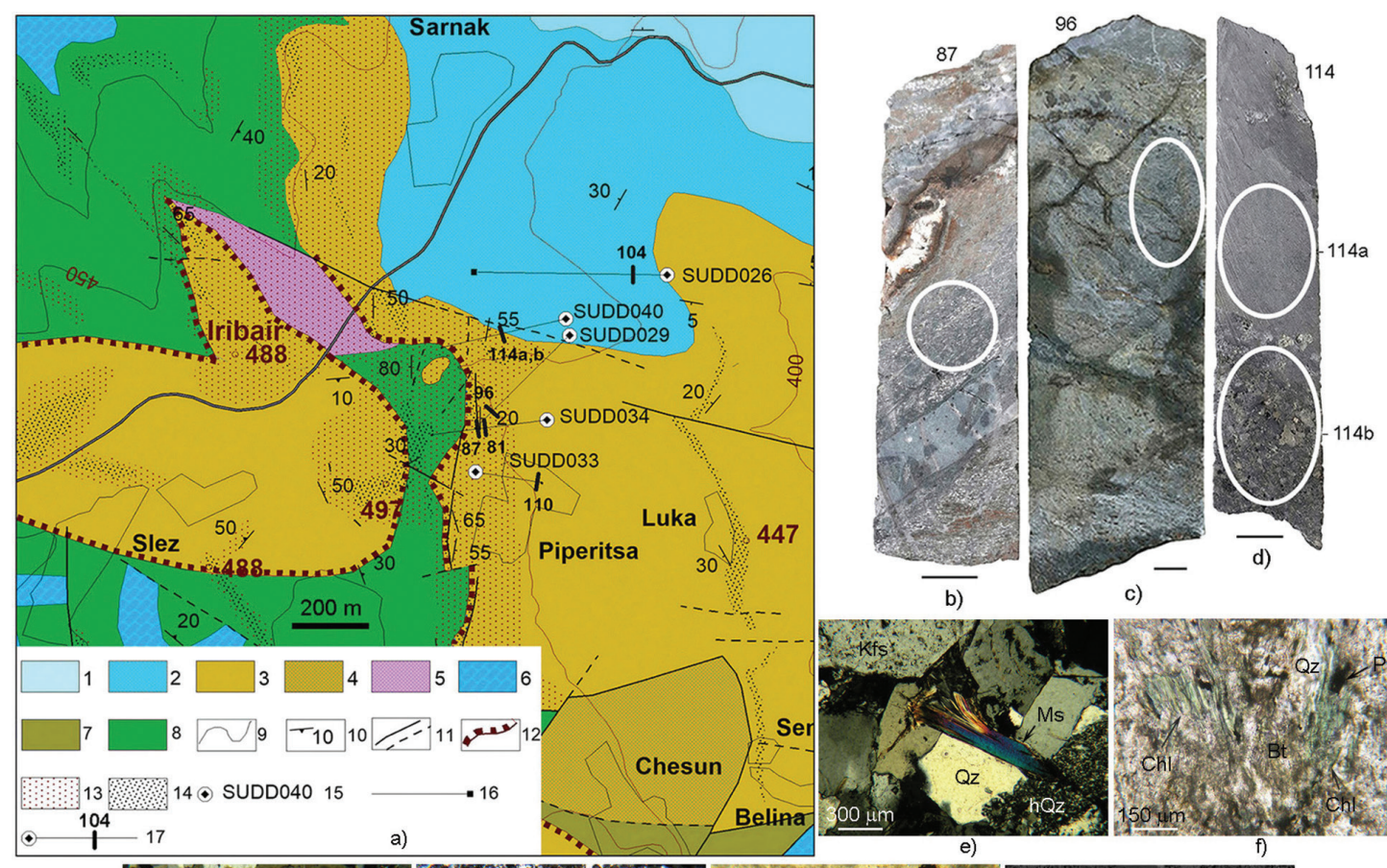

b)
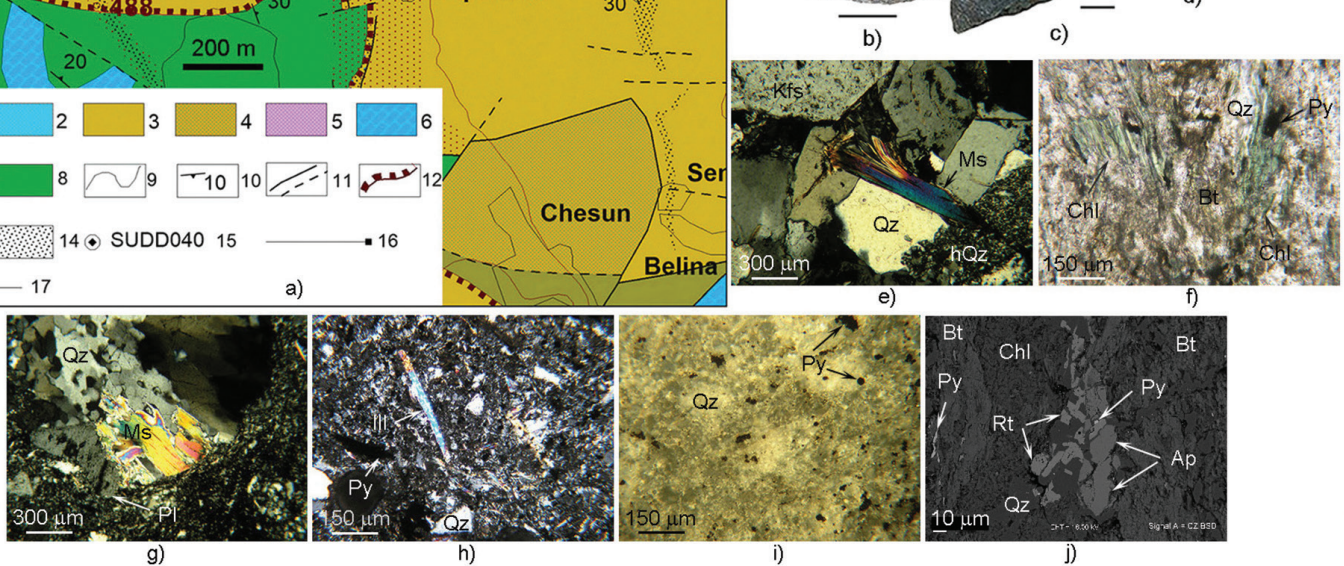

g)

h)

Fig. 1. $a$, geological map of part of the Sarnak deposit (courtesy of DPMK): Eocene: 1-2, marly-limestone formation: 1, thin bedded calcareous sandstone and limestone, siltstone, marl, 2, organogenic reef limestone and marl; 3, coal-bearing-sandstone formation; Paleocene: 4, continental terrigenous formation (Kroumovgrad Group); pre-Paleocene basement: 5, granitic pegmatite, 6, marble and calc-shist, 7, amphibolite and gneiss, 8, amphibolite; 9, geological boundary; 10, foliation/bedding; 11, fault (left, traced; right, supposed); 12, Tokachka detachment fault; 13, argilization; 14, moderate silicification; 15, sampled drill hole; 16, horizontal drill hole trace; 17 , localisation sample; $b-d$, rock samples (scale bar $1 \mathrm{~cm}$ ): metamorphic basement: $b, 87-$ foliated rock; $c, 96$ - massive rock; sedimentary cover: $d, 114 \mathrm{a}$ - aleurolite, $114 \mathrm{~b}$ - medium-grained sandstone; $e-i$, photomicrographs in transmitted light: $e, 87$ - K-feldspar, muscovite and quartz cross-cut by hydrothermal microcrystalline quartz; $f$, 110 - biotite altered by chlorite and quartz along foliation planes; $g, 104$-foliated metamorphic rock composed of quartz, muscovite and plagioclase, cemented by quartz, clays and Fe-hydroxide; $h-i, 114 \mathrm{a}$ - detrital quartz, newly formed illite and cement of clay and framboidal pyrite; $j$, BSE-image of sample 87 - chloritized biotite and quartz-rutile-pyrite veinlet; $(e, g$ - $h$, cross-polarized light; $f$, $i$, plain-polarized light). Abbr.: $K f s$, K-feldspar; $P l$, plagioclase; $B t$, biotite; $M s$, muscovite; $C h l$, chlorite; $h Q z$, hydrothermal quartz; $P y$, pyrite; $R t$, rutile; $A p$, apatite; Ill, illite.

biotite gneisses. The sedimentary section starts with the Paleocene continental terrigenous formation (Kroumovgrad Group), followed by two Eocene formations: coal-bearing-sandstone formation and marly-limestone formation (Fig. 1a) (Jelev, 2004f ${ }^{1}$ ).

\section{Results}

Petrography. Three samples were collected from the metamorphic basement $-87,96$ and 110 (Figs 1b-c). Samples 87 and 110 are grey-green rocks with a distinct foliation defined by grey-green and white bands,

${ }^{1}$ Jelev, D. 2004f. Report on the Results of the Geological Prospecting and Evaluation of Gold-bearing Ores in Krumovgrad Area, with Calculation of Reserves and Resources in Khan Krum Deposit, Sections Ada Tepe, Sarnak, Skalak, Sinap, Kaklitsa and Kupel, Kardzhali District, as of 01.09.2004. DPMK, 235 p. (in Bulgarian). while the sample 96 is a green, massive rock. Under an optical microscope the samples 87 and 110 consist of sericitized K-feldspar, plagioclase, muscovite, chloritized biotite, and quartz ( $<1 \mathrm{~mm}$ in size). In sample 87 , feldspar, mica and quartz grains preserved a magmatic texture (Fig. 1e), while in sample 110 the foliation is well expressed (Fig. 1f). Few euhedral zircon and monazite $(\sim 50 \mu \mathrm{m}$ in size $)$, and anhedral titanite grains (up to $300 \mu \mathrm{m}$ ) were observed. The powder Xray analysis of the sample 96 indicates the presence of chlorite, illite, muscovite, K-feldspar, plagioclase, pyrite and quartz as the main mineral (pointing to a silicification), and is identical to those of the sample 87 . Four samples from the sedimentary cover are selected: 81 (clast-supported breccia-conglomerate, comprising clasts of a foliated grey metamorphic 
rock), 104 (fine-grained sandstone), 114a (aleurolite) and 114b (medium-grained sandstone) (Fig. 1d). Under optical microscope, the foliated clast in sample 81 consists of K-feldspar, plagioclase, muscovite, quartz, and pyrite, and is intersected by quartz-pyrite veinlets. Feldspar is replaced by sericite and clay mineral. Supergene Fe-hydroxides filled microfractures. The sandstone samples consist of detrital metamorphic and magmatic quartz, K-feldspar, lamellar plagioclase, muscovite, and sub-millimetric clasts of metamorphic rocks. Feldspar is $\sim 25$ vol.\%, thus defining the sandstone as arkose. The sandstone matrix is composed of quartz and Fe-hydroxides; locally illite, chlorite, pyrite and clays are observed (Fig. 1g). In sample $114 \mathrm{~b}$ the dispersed pyrite in the grain interstices is visible by naked eye (Fig. 1d, bottom). Optically, in the aleurolite detrital quartz, minor feldspar, and rare muscovite flakes are recognized, confirmed also by X-ray analysis. Monazite and zircon grains are scarce. The matrix consists of illite and clays, in places chlorite. Pyrite appear as dispersed framboids, a few $\mu \mathrm{m}$ in diameter (Fig. $1 \mathrm{~h}-\mathrm{i}$ ).

Wall rock alteration. The most pronounced metasomatic alterations of the metamorphic rocks studied are sericitization of K-feldspar and chloritization of biotite. Sericite appears as numerous grains, a few $\mu \mathrm{m}$ in diameter (Fig. 1e). Chlorite is light (Figs 1f). Kaolinization is ubiquitous. Kaolinite (several EDX spectra for identification) forms very fine flakes $(<10 \mu \mathrm{m}$ long) mainly in pores, grain interstices and hairline veinlets but also alters plagioclase (albite to EDX spectra). Rare epidote veinlets intersect the rocks. Rutile is often seen along the cleavage of biotite and chlorite as well as in quartz-pyrite veinlets. It forms elongated crystals 10-20 $\mu \mathrm{m}$ long (Fig. 1j). Disseminated pyrite is very fine-grained (a few $\mu \mathrm{m}$ in size). Later quartz-pyrite, quartz-adularia-pyrite and carbonate veinlets cut the rocks. Adularia forms pseudorhombic crystals, commonly $\sim 10-50 \mu \mathrm{m}$ in diameter, rarely more. Silicification is widespread, as microcrystalline quartz (mostly $\sim 10-50 \mu \mathrm{m}$ and up to $100-200 \mu \mathrm{m}$ in size) is developed along schistosity, in spots and along fractures (Fig. 1e-f). The most pronounced alteration in the arkose and aleurolite is the pyritization - pyrite commonly formed dispersed grains and more rarely thin veinlets.

\section{Discussion and conclusions}

The microscopic observations revealed that the metamorphic samples are of metagranite and two-mica gneiss composition. Their oldest alterations appear formation of epidote, chlorite, albite, sericite, and accompanying very fine-grained, disseminated pyrite, which have a character of greenstone alteration (Velinov et al., 1999). Likely kaolinite is related to this kind of alteration (Kunov et al., 1999), but this issue needs further clarification. The metamorphic rocks are crosscut by quartz-rutile veinlets. Rutile belongs to the greenstone alteration since this mineral is documented at greenschist facies conditions (Porter et al., 2020). The sedimentary rocks contain dispersed framboidal pyrite which could be diagenetic. Later, quartz \pm adularia-pyrite veinlets intersected both the metamorphic and sedimentary rocks. They are related to the epithermal mineralization since they bear arsenian pyrite; rare arsenopyrite, galena, sphalerite, chalcopyrite, marcasite, tetrahedrite, acanthite, and other ore minerals (own unpubl. data). Hydrothermal pyrite in all the samples studied (except for 87) is mostly deposited in open space: voids, mineral interstices, mineral cleavage, and cracks. In strongly fractured rocks in fault zones, the pyrite replacement of the rock-forming minerals is common (sample 87). The widespread presence of adularia in quartz-pyrite veinlets implies episodes of a boiling of hydrothermal fluids (Browne, 1978). Epidote is indicative of temperature above $240-260{ }^{\circ} \mathrm{C}$ (Browne, 1978) whereas the hydrothermal quartz recorded lower temperature for the epithermal mineralization in the Sarnak deposit - 250-200 ${ }^{\circ} \mathrm{C}$ homogenization temperature of fluid inclusions (Christova, 1996; Marton, 2009). Thus the greenstone alteration formation is unrelated to that of the epithermal mineralization.

Acknowledgements: The authors thank DPMK for permission to sample and financial support. Thanks are due for the technical support from the project PERIMED BG05M2OP001-1.002-0005/29.03.2018 (2018-2023). The authors are grateful to M. Tarassov (IMC) for help during SEM-EDX analyses.

\section{References}

Browne, P. R. L. 1978. Hydrothermal alteration in active geothermal fields. - Ann. Rev. Earth Planet. Sci., 6, 229-250; https://doi.org/10.1146/annurev.ea.06.050178.001305.

Christova, J. 1996. Temperature, composition and salinity of gold-bearing fluid systems in pre-Alpine and Alpine ore deposits in Bulgaria (according to microthermometric studies of quartz). - C. R. Acad. Bulg. Sci., 49, 85- 88.

Kunov, A., J. Christova, V. Stamatova, R. Atanasova. 1999. Wall-rock alterations and character of ore-metasomatic systems in some gold and gold-bearing deposits and occurrences in Bulgaria. - Proc. Nat. Confer. "Metallogeny of Bulgaria”, 58-61 (in Bulgarian).

Marton, I. 2009. Formation, Preservation and Exhumation of Sedimentary Rock-hosted Gold Deposits in the Eastern Rhodopes, Bulgaria. PhD Thesis, Terre \& Environment, $84,134 \mathrm{pp}$.

Porter, J. K., N. J. McNaughton, N. J. Evans, B. J. McDonald. 2020. Rutile as a pathfinder for metals exploration. - Ore Geol. Rev., 120, 103406; https://doi.org/10.1016/j.oregeorev.2020.103406.

Velinov, I., A. Kunov, K. Michael, R. Petrunov. 1999. Mineralogy and zonality of hydrothermally altered volcanic rocks bearing gold-silver epithermal mineralizations. Case studies from Bulgaria, Greece and Turkey. - Proc. Nat. Confer. "Metallogeny of Bulgaria", 9-11 (in Bulgarian). 